\title{
Rotifer communities of Deepor Beel, Assam, India: richness, abundance and ecology
}

\author{
B.K. Sharma
}

Department of Zoology, North-Eastern Hill University, Permanent Campus, Umshing, Shillong, Meghalaya 793022, India Email: bksharma@nehu.ac.in

\begin{abstract}
Plankton samples collected from two sampling stations of Deepor Beel (a Ramsar site in Assam, northeastern India) between November 2002 and October 2003, reveal 110 and 100 species of Rotifera, exhibit monthly richness ranging between 43-65 (56 \pm 6$)$ and 38-60 (52 \pm 7$)$ species and record 48.9-88.1 and 53.1-89.7\% community similarities respectively. Rotifera $(231 \pm 60$ and $198 \pm 70$ $\mathrm{n} / \mathrm{I})$ comprise between $48.7 \pm 6.1$ and $42.6 \pm 4.1 \%$ of zooplankton abundance at station I and II respectively, and follow trimodal annual patterns with peaks during winter. Brachionidae $(90 \pm 43,79 \pm 39 \mathrm{n} / \mathrm{l})>$ Lecanidae $(45 \pm 13,29 \pm 9 \mathrm{n} / \mathrm{l})$ form important quantitative components of Rotifera while Asplanchnidae $>$ Synchaetidae $>$ Trochosphaeridae are other notable families. Lecane $>$ Brachionus $>$ Keratella > Asplanchna > Platyias contribute notably to temporal variations of the rotifers. Asplanchna priodonta, Keratella cochlearis, Platyias quadricornis, Lecane leontina, Polyarthra vulgaris, Keratella tropica and Brachionus falcatus are important species. Analysis of variance comparisons indicate significant temporal variations in richness and abundance of Rotifera between stations and months. The rotifer communities exhibit higher species diversity, higher evenness, lower dominance and lack of quantitative dominance of any individual species. The present results show no definite periodicity of richness and abundance of this group, families or species. Individual abiotic factors register limited influence on richness and abundance while multiple regression exhibits higher cumulative influence of ten abiotic factors on these parameters at both sampling stations.
\end{abstract}

Key words: Abundance, Deepor Beel, ecology, Ramsar site, Rotifera, richness.

Date of publication (online): 26 July 2010 Date of publication (print): 26 July 2010 ISSN $0974-7907$ (online) | 0974-7893 (print)

Editor: M.M. Saxena

\section{Manuscript details:}

Ms \# 02411

Received 24 February 2010

Finally accepted 29 June 2010

Citation: Sharma, B.K. (2010). Rotifer communities of Deepor Beel, Assam, India: richness, abundance and ecology. Journal of Threatened Taxa 2(8): 1077-1086.

Copyright: () B.K. Sharma 2010. Creative Commons Attribution 3.0 Unported License. JoTT allows unrestricted use of this article in any medium for non-profit purposes, reproduction and distribution by providing adequate credit to the authors and the source of publication.

Author Details: B.K. SHARMA is a Professor in Department of Zoology and Dean, School of Life Sciences and is a specialist in the fields of limnology and acquatic biodiversity

Acknowledgements: This study is undertaken partly under the "Potential for Excellence Program (Focused Area: Biosciences) of North-Eastern Hil University, Shillong. The author is thankful to the G.B. Pant Institute of Himalayan Environmental Development, Almora for a research grant during which this study was initiated. The author is grateful to Dr. (Mrs.) Sumita Sharma, Eastern Regional Station, Zoological Survey of India, Shillong for useful comments. Thanks are due to the Head, Department of Zoology, North-Eastern Hill University, Shillong for necessary laboratory facilities.

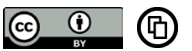

OPEN ACCESS | FREE DOWNLOAD

\section{INTRODUCTION}

Rotifera are important qualitative and quantitative components of zooplankton in freshwater ecosystems, comprising integral links of aquatic food-webs (primarily as fish food) and contributing significantly to secondary productivity. These organisms have been studied in a wide variety of Indian freshwater biotopes for more than a century, yet there is limited information on their ecology and role in aquatic productivity in floodplain lakes (Sharma \& Sharma 2008). Earlier studies of Rotifera in the floodplains of Northeastern India mainly relate to biodiversity (Sharma 2000a, 2005; Sharma \& Sharma 2001, 2008) and ecology in specific locations in Assam (Sharma 2000b, 2006), and the present study extends this work to characterize the Rotifera of Deepor Beel, an important floodplain lake of the Brahmaputra River basin. Qualitative and quantitative analyses of the rotifer communities are presented describing temporal variations in richness, community similarities, abundance, species diversity, dominance and evenness. In addition, the influences of abiotic parameters on occurrence and abundance of Rotifera are analyzed in order to understand ecological relationships.

\section{MATERIALS AND METHODS}

The present study is a part of limnological survey undertaken during

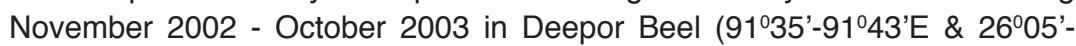
$26^{0} 11^{\prime} \mathrm{N}$; area: $40 \mathrm{~km}^{2}$; altitude: $42 \mathrm{~m}$ ) located in the Kamrup District of lower Assam (N.E. India). This floodplain lake is covered with various aquatic macrophytes namely Hydrilla verticellata, Eichhornia crassipes, Vallisnaria spiralis, Utricularia flexuosa, Trapa bispinosa, Euryale ferox, Najas indica, Monochoria hastaefolia, Ipomoea fistulosa, Hygroryza aristata, Polygonum hydropiper and Limnophila sp.

Water samples were collected monthly from two sampling stations (I and 
II) and were analyzed for various abiotic factors. Water temperature, specific conductivity and $\mathrm{pH}$ were recorded by field probes, transparency was noted with Secchi disc, dissolved oxygen was estimated by modified Winkler's methods and other parameters were analyzed following APHA (1992). Monthly qualitative (by towing) and quantitative (by filtering 25 I water each) plankton samples were collected by nylobolt plankton net (No. 25) and were preserved in $5 \%$ formalin. The former were screened for the rotifer species and quantitative collections were analyzed for their abundance. Rotifera species were identified following Koste (1978), Segers (1995), Sharma (1998), and Sharma \& Sharma (1999, 2000).

Community similarities (Sorensen's index), species diversity (Shannon's index), dominance (Berger-Parker's index) and evenness (E1 index) were calculated following Ludwig \& Reynolds (1988) and Magurran (1988). ANOVA (two-way) was used to analyse significance of temporal variations of biotic communities. Simple correlation coefficients $\left(r_{1}\right.$ and $\left.r_{2}\right)$ were calculated between abiotic and biotic parameters while multiple regressions $\left(R^{2}\right.$ and $\mathrm{R}_{2}^{2}$ ) were computed with ten abiotic factors i.e., water temperature, rainfall, $\mathrm{pH}$, transparency, specific conductivity, dissolved oxygen, alkalinity, hardness, phosphate and nitrate for both sampling stations respectively.

\section{RESULTS AND DISCUSSION}

Water samples analyzed from Deepor Beel are characterized (Table 1) by low ionic concentrations and thus warrant inclusion of this Ramsar site under 'Class I' category following Talling \& Talling (1965). Mean water temperature affirms tropical range concurrent with its geographical location. The circum-neutral and marginally hard waters of this wetland record moderate dissolved oxygen, low free $\mathrm{CO}_{2}$ and low concentration of micronutrients. In general, the ranges of the recorded abiotic factors are generally concurrent at both sampling stations (I and II).

Plankton samples examined from Deepor Beel reveal 110 species of Rotifera belonging to 35 genera and 19 families, comprise about $54.5 \%$ of the species known from Northeastern India (Sharma \& Sharma 2005) and represent about $30.5 \%$ of the Indian Rotifera and, hence, highly speciose and diverse nature of the rotifer biocoenosis. The examined diversity reflects greater environmental heterogeneity and habitat diversity of Deepor Beel and, in turn, affirms hypothesis of Segers et al. (1993) indicating (sub) tropical floodplain lakes to be the world's richest habitats for the rotifer diversity. Further, the present report follows next to the highest Indian record of 120 species from Loktak Lake (Sharma 2009), Manipuranother Ramsar site. The rotifers comprise the dominant qualitative component of zooplankton (171 species) of
Table 1. Temporal variations of abiotic factors

\begin{tabular}{|c|c|c|}
\hline Factors & Station I & Station II \\
\hline Rainfall (mm) & $204.5 \pm 160.4$ & $204.5 \pm 160.4$ \\
\hline Water temperature $\left({ }^{\circ} \mathrm{C}\right)$ & $27.2 \pm 4.6$ & $27.4 \pm 5.1$ \\
\hline $\mathrm{pH}$ & $6.89 \pm 0.18$ & $6.93 \pm 0.21$ \\
\hline Transparency (cm) & $51.9 \pm 26.2$ & $52.7 \pm 25.3$ \\
\hline Specific conductivity $(\mu \mathrm{S} / \mathrm{cm})$ & $99.2 \pm 13.2$ & $96.8 \pm 15.5$ \\
\hline Dissolved oxygen (mg/l) & $6.7 \pm 1.6$ & $7.0 \pm 1.1$ \\
\hline Free $\mathrm{CO}_{2}(\mathrm{mg} / \mathrm{l})$ & $7.2 \pm 2.1$ & $6.8 \pm 1.9$ \\
\hline Alkalinity (mg/l) & $66.3 \pm 12.1$ & $68.9 \pm 10.3$ \\
\hline Hardness (mg/l) & $62.1 \pm 9.9$ & $61.2 \pm 12.3$ \\
\hline Calcium (mg/l) & $20.1 \pm 2.2$ & $22.1 \pm 1.8$ \\
\hline Magnesium (mg/l) & $4.0 \pm 0.7$ & $4.2 \pm 0.9$ \\
\hline Chloride (mg/l) & $34.6 \pm 5.2$ & $35.1 \pm 5.0$ \\
\hline Phosphate (mg/l) & $0.18 \pm 0.07$ & $0.19 \pm 0.10$ \\
\hline Sulphate (mg/l) & $10.2 \pm 3.2$ & $9.9 \pm 3.4$ \\
\hline Nitrate $(\mathrm{mg} / \mathrm{l})$ & $0.72 \pm 0.12$ & $0.74 \pm 0.14$ \\
\hline Silicate $(\mathrm{mg} / \mathrm{l})$ & $3.02 \pm 1.02$ & $3.10 \pm 1.27$ \\
\hline B.O. $D_{5}(\mathrm{mg} / \mathrm{l})$ & $3.11 \pm 0.59$ & $3.21 \pm 0.46$ \\
\hline Dissolved organic matter $(\mathrm{mg} / \mathrm{l})$ & $3.84 \pm 0.80$ & $3.90 \pm 0.64$ \\
\hline Total dissolved solids (mg/l) & $2.37 \pm 0.29$ & $2.57 \pm 0.30$ \\
\hline
\end{tabular}

Deepor Beel (Table 2). The present report even exceeds earlier lists of 67-103 species (Sharma 2005) and 6993 species (Sharma \& Sharma 2008) recorded from 15 floodplain lakes (beels) each of Assam. Rotifera richness is, however, significantly higher than the reports of 48 species from 37 beels (Sarma 2000), 64 species from five beels (Sharma 2000a) and 64 species from twelve beels of the Pobitora Wildlife Sanctuary (Sharma 2006) of Assam state; 27 species from two floodplain lakes of Kashmir (Khan 1987) and 38 species from four ox-bow lakes and nine floodplain lakes of South-eastern West Bengal (Khan 2003).

All the examined species are observed at station I while 100 species are recorded at station II. Their monthly richness (Table 2), however, varies between 43-65 (56 \pm 6) and 38-60 (52 \pm 7$)$ species, exhibits (Fig. 1) trimodal and multimodal annual patterns with peaks during January and November at two stations respectively and minima during summer (April) each. Richness registers significant temporal variations between stations $\left(F_{1,23}=8.696, p<\right.$ $0.01)$ and months $\left(F_{11,23}=9.472, p<0.005\right)$. Rotifera form main qualitative component of zooplankton (58.4 \pm 2.1 and $53.0 \pm 4.9 \%$ ) during the study period at Stations I and II and distinctly influence their temporal variations $\left(r_{1}=0.969, r_{2}=0.918\right)$. In general, this group follows no definite qualitative trend except for more number of 


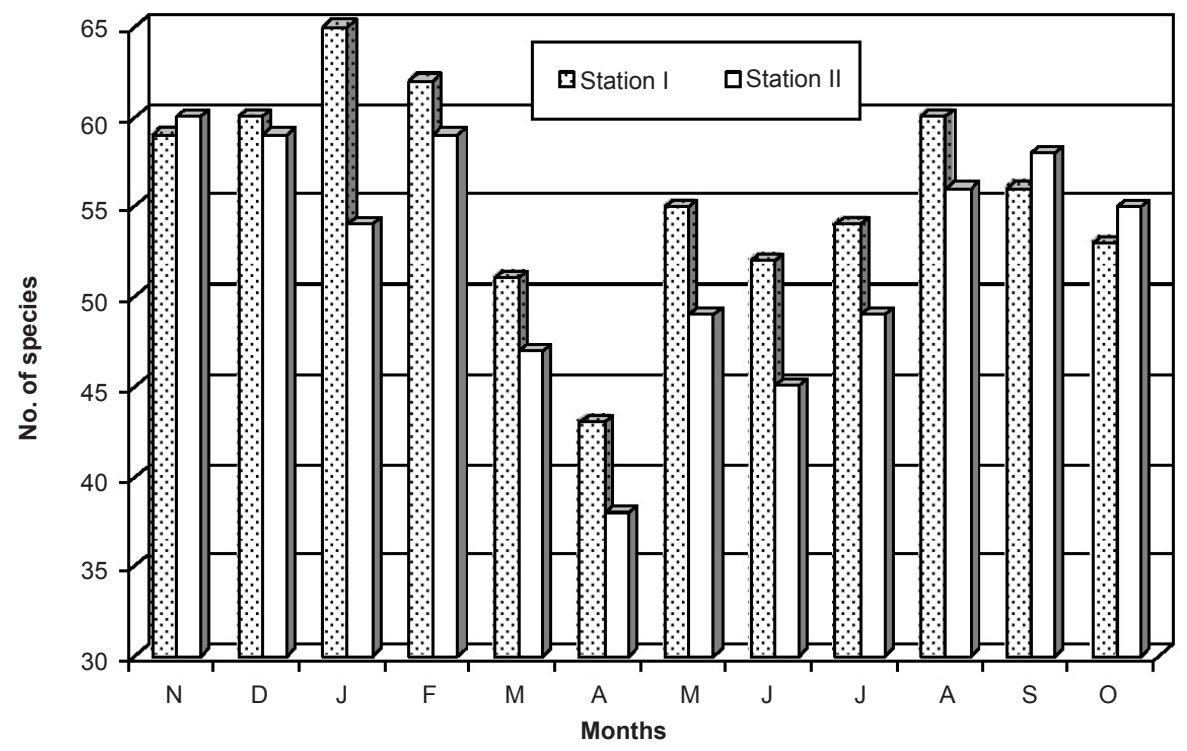

Figure 1. Monthly variations in richness of Rotifera

species during winter; the latter feature is supported by significant negative correlation with water temperature $\left(r_{1}\right.$ $\left.=-0.724, r_{2}=-0.577\right)$. Rotifera richness is also negatively correlated with rainfall $\left(r_{1}=-0.473, r_{2}=-0.587\right)$ at both stations while it is positively correlated with transparency $\left(r_{2}=0.554\right)$, specific conductivity $\left(r_{2}=0.570\right)$, dissolved oxygen $\left(r_{2}=0.732\right)$, alkalinity $\left(r_{2}=0.563\right)$, hardness $\left(r_{2}=\right.$ $0.503)$ and phosphate $\left(r_{2}=0.520\right)$ at station II. Multiple regression indicates higher cumulative effect of 10 abiotic factors on their richness $\left(R_{1}^{2}=0.881, R_{2}^{2}=0.928\right)$ at both sampling stations.

The rotifer communities indicate $48.9-88.1 \%$ similarity at Station I and marginally higher range (53.1-89.7\%) at Station II (Tables $3 \& 4$ ). This study shows few instances of $<60.0 \%$ or $>80.0 \%$ similarities while it varies between $60-70 \%$ in 38.4 and $34.8 \%$ instances and between 70 $80 \%$ in 43.9 and $53.3 \%$ instances at two sampling stations respectively, thereby, indicating relatively higher similarities in their species composition. Peak similarities are observed between November-February and December-January at two stations respectively. Cluster analysis indicates more differences of their monthly groupings at station II in general. The rotifer communities at station I show (Fig. 2) higher affinities between November-February and again between July-August while greater divergence is noticed during April. On the other hand, higher affinities at station II are noticed (Fig. 3) between December-January and February-October while June, July, March, May and April communities show greater divergence in their composition.

Rotifera $(231 \pm 60$ and $198 \pm 90 \mathrm{n} / \mathrm{l})$ form (Table 2) an important quantitative component $(48.7 \pm 6.1$ and 42.5 $\pm 4.1 \%$ ) of zooplankton and contribute significantly to temporal variations of the latter $\left(r_{1}=0.896, r_{2}=0.970\right)$ at both sampling stations. Quantitative dominance of this group concurs with the results of Khan (1987), Sanjer \& Sharma (1995), Sharma \& Sharma $(2001,2008)$ and Sharma $(2005,2006)$ but differs from their sub-dominant role noticed by Baruah et al. (1993), Sharma (2000b) and Khan (2002). Abundance registers significant variations between stations $\left(F_{1,23 .}=9.387, p<0.01\right)$ as well as months $\left(F_{11,23}=11.279, p>0.005\right)$. Further, it follows (Fig. 4 and 5) broadly identical trimodal patterns without any definite periodicity at two sampling stations but record higher abundance $(<250 \mathrm{n} / \mathrm{l})$ during winter with peaks during January each. The last feature is supported by their significant negative correlation with water temperature $\left(r_{1}=-0.725, r_{2}=-0.919\right)$. In addition, abundance is positively correlated with transparency $\left(r_{1}\right.$ $\left.=0.597, r_{2}=0.640\right)$, specific conductivity $\left(r_{1}=0.453, r_{2}\right.$ $=0.684)$, dissolved oxygen $\left(r_{1}=0.470, r_{2}=0.677\right)$ and $\mathrm{BOD}_{5}\left(r_{1}=0.510, r_{2}=0.494\right)$ at both stations while it is negatively correlated with rainfall $\left(r_{2}=-0.595\right)$ and free $\mathrm{CO}_{2}\left(r_{2}=-0.555\right)$, and positively correlated with alkalinity $\left(r_{2}=0.601\right)$ and hardness $\left(r_{2}=0.690\right)$ and chloride $\left(r_{2}=\right.$ 0.479 ) at station II. Multiple regression indicates higher cumulative effect of 10 abiotic factors on abundance $\left(R_{1}{ }^{2}\right.$ $=0.966, R_{2}{ }^{2}=0.977$ ) at both stations. Rotifera abundance also indicates significant positive correlation with their richness $\left(r_{1}=0.745, r_{2}=0.614\right)$.

In general, Rotifera abundance of Deepor Beel is higher than the reports of Yadava et al. (1987), Baruah et al. (1993), Sinha et al. (1994), Sharma $(2000,2005)$ and Sharma \& Sharma $(2001,2008)$; it is lower than the results of Khan (1987) and Sanjer \& Sharma (1995) while the density broadly concurs with the results of Sharma (2006). Further, winter peaks observed in this study concur with the results of Sharma (2000b); this trend is, however, in contrast to summer maxima noticed by Yadava et al. (1987) from floodplain lakes of Assam, and by Baruah et 
Table 2. Temporal variations of rotifer communities

\begin{tabular}{|c|c|c|}
\hline QUALITATIVE & Station I & Station II \\
\hline $\begin{array}{l}\text { Zooplankton } \\
\text { Monthly richness }\end{array}$ & $\begin{array}{c}171 \text { species } \\
68-112(96 \pm 11)\end{array}$ & $\begin{array}{c}160 \text { species } \\
68-85(97 \pm 13)\end{array}$ \\
\hline $\begin{array}{l}\text { Rotifera } \\
\text { Monthly richness } \\
\% \text { of zooplankton richness }\end{array}$ & $\begin{array}{c}110 \text { species } \\
43-65(56 \pm 6) \\
54.5-63.2(58.4 \pm 2.1)\end{array}$ & $\begin{array}{c}100 \text { species } \\
38-60(52 \pm 7) \\
42.2-58.3(53.0 \pm 4.2)\end{array}$ \\
\hline \multicolumn{3}{|l|}{ QUANTITATIVE } \\
\hline Zooplankton & $289-657(475 \pm 114)$ & $255-687(459 \pm 128)$ \\
\hline $\begin{array}{l}\text { Rotifera } \\
\text { Percentage }\end{array}$ & $\begin{array}{c}105-318(231 \pm 60) \\
42.8-65.2(48.7 \pm 6.1)\end{array}$ & $\begin{array}{c}106-325(198 \pm 70) \\
37.9-49.6(42.5 \pm 4.1)\end{array}$ \\
\hline Diversity & $3.104-3.982(3.415 \pm 0.288)$ & $3.156-3.597(3.341 \pm 0.158)$ \\
\hline Dominance & $0.208-0.328(0.257 \pm 0.035)$ & $0.221-0.336(0.260 \pm 0.034)$ \\
\hline Evenness & $0.758-0.969(0.847 \pm 0.066)$ & $0.776-0.901(0.848 \pm 0.037)$ \\
\hline \multicolumn{3}{|l|}{ Important families } \\
\hline $\begin{array}{l}\text { Brachionidae } \\
\text { Percentage }\end{array}$ & $\begin{array}{c}33-172(90 \pm 43) \\
22.5-66.4(37.8 \pm 12.7)\end{array}$ & $\begin{aligned} 58-152 & (79 \pm 39) \\
21.2-54.1 & (39.1 \pm 9.9)\end{aligned}$ \\
\hline $\begin{array}{l}\text { Lecanidae } \\
\text { Percentage }\end{array}$ & $\begin{array}{c}27-65(45 \pm 13) \\
12.3-31.5(20.3 \pm 9.9)\end{array}$ & $\begin{array}{c}17-48(29 \pm 9) \\
15.0 \pm 3.9\end{array}$ \\
\hline $\begin{array}{l}\text { Asplanchnidae } \\
\text { Percentage }\end{array}$ & $\begin{array}{c}2-60(19 \pm 5) \\
1.9-19.3(7.3 \pm 4.9)\end{array}$ & $\begin{array}{c}1-42(18 \pm 13) \\
2.8-16.8(8.1 \pm 4.8)\end{array}$ \\
\hline Synchaetidae & $2-30(11 \pm 9)$ & $2-26(13 \pm 8)$ \\
\hline Trochosphaeridae & $1-33(11 \pm 8)$ & $2-22(10 \pm 6)$ \\
\hline Trichocercidae & $4-16(10 \pm 4)$ & $3-9(6 \pm 2)$ \\
\hline Lepadellidae & $6-14(10 \pm 3)$ & $4-13(7 \pm 3)$ \\
\hline \multicolumn{3}{|l|}{ Important genera } \\
\hline Lecane & $27-65(45 \pm 13)$ & $17-48(29 \pm 9)$ \\
\hline Brachionus & $21-111(43 \pm 29)$ & $15-83(33 \pm 23)$ \\
\hline Keratella & $5-76(30 \pm 20)$ & $14-67(33 \pm 16)$ \\
\hline Asplanchna & $2-60(19 \pm 5)$ & $1-42(18 \pm 13)$ \\
\hline Platyias & $2-32(14 \pm 9)$ & $1-30(11 \pm 8)$ \\
\hline \multicolumn{3}{|l|}{ Important species } \\
\hline Asplanchna prioodonta $(\mathrm{n} / \mathrm{l})$ & $2-60(19 \pm 5)$ & $1-42(18 \pm 13)$ \\
\hline Keratella cochlearis $\quad(n / l)$ & $2-52(16 \pm 15)$ & $4-38(10 \pm 13)$ \\
\hline Platyias quadricornis $\quad(\mathrm{n} / \mathrm{l})$ & $3-32(14 \pm 18)$ & $1-30(10 \pm 8)$ \\
\hline Lecane leontina & $2-35(14 \pm 10)$ & $1-15(6 \pm 4)$ \\
\hline Polyarthra vulgaris $\quad(\mathrm{n} / \mathrm{l})$ & $2-30(11 \pm 9)$ & $2-26(13 \pm 8)$ \\
\hline Keratella tropica & $1-30(9 \pm 10)$ & $2-32(10 \pm 9)$ \\
\hline Brachionus falcatus & $1-35(9 \pm 10)$ & $11-31(8 \pm 9)$ \\
\hline
\end{tabular}

al. (1993), and Sanjer \& Sharma (1995) from Bihar as well as autumn maxima recorded in the floodplains of the Kashmir valley (Khan 1987). The present study records no definite seasonal periodicity of abundance of loricate or illoricate rotifers as reported earlier by Sharma (1992).

Brachionidae $(90 \pm 43$ and $79 \pm 30 \mathrm{n} / \mathrm{l})$, the dominant family, comprises an important quantitative component $(37.8 \pm 12.7$ and $39.1 \pm 9.9 \%)$ of Rotifera (Table 2$)$ and distinctly contribute to temporal variations of the latter $\left(r_{1}=0.724, r_{2}=0.877\right)$ at both sampling stations. The stated trend supports earlier remarks of Sharma (2000b, 2006). The brachionids record significant quantitative variations between months $\left(F_{11,23}=19.187, p>0.005\right)$ and insignificant variations between stations. This family follows trimodal annual patterns (Figs. 4 \& 5) which are characterized by higher abundance during December- 


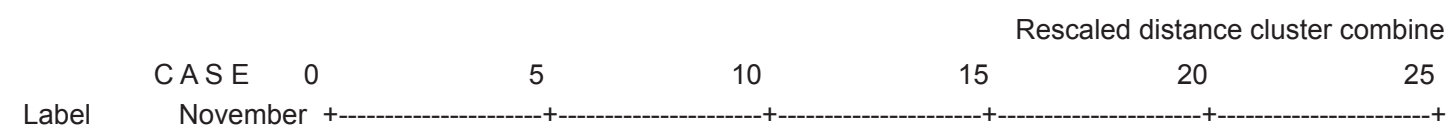

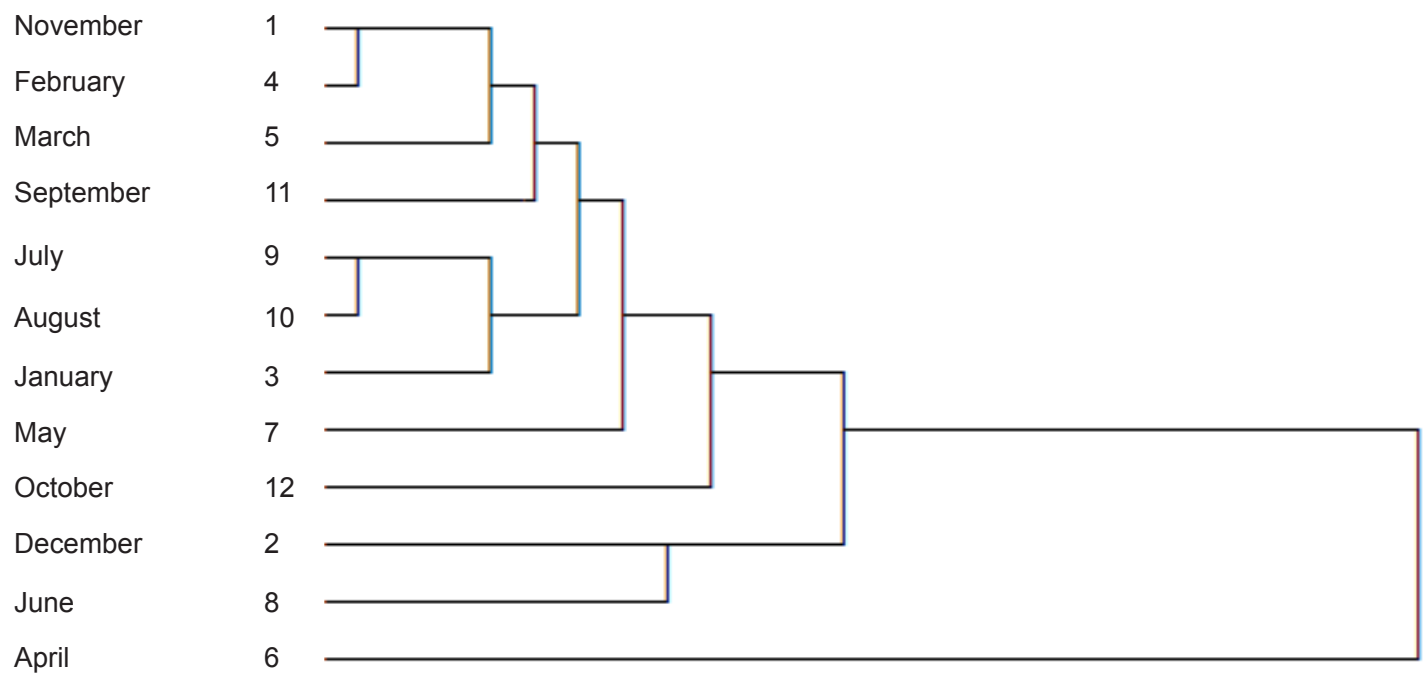

Figure 2. Hierarchical cluster analysis of Rotifera (Station I)

\begin{tabular}{|c|c|c|c|c|c|c|}
\hline \multirow[b]{2}{*}{ CASE } & \multirow[b]{2}{*}{0} & \multirow[b]{2}{*}{5} & \multirow[b]{2}{*}{10} & \multicolumn{3}{|c|}{ Rescaled distance cluster combine } \\
\hline & & & & 15 & 20 & 25 \\
\hline
\end{tabular}

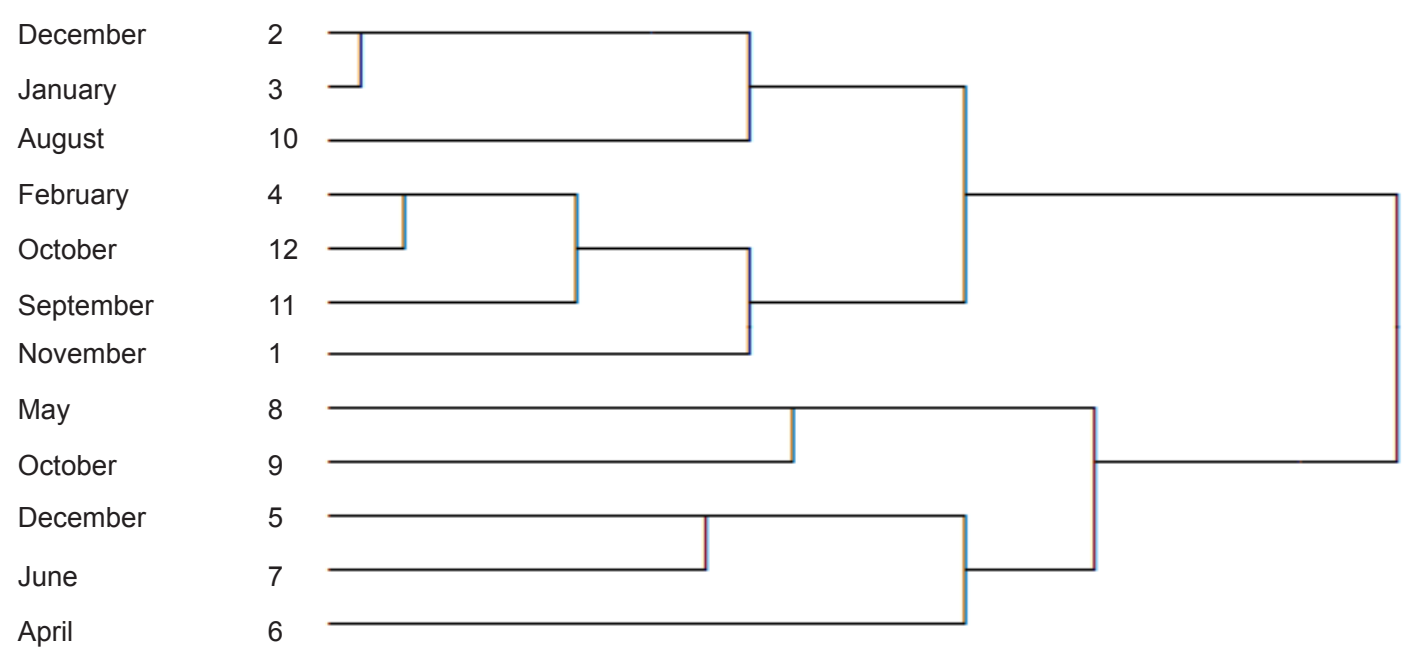

Figure 3. Hierarchical cluster analysis of Rotifera (Station II)

March with peaks during February (station I) and January (station II) while lower densities are noticed during AprilMay and July-October with minima during April at both the sampling stations. The former feature is affirmed by their significant negative correlation with water temperature $\left(r_{1}=-0.573, r_{2}=-0.786\right)$. In addition, they are negatively correlated with Magnesium at station I $\left(r_{1}=-0.799\right)$ and with free $\mathrm{CO}_{2}$ at station II $\left(r_{2}=-0.492\right)$. Besides, this family is positively correlated with specific conductivity $\left(r_{1}=\right.$ $\left.0.580, r_{2}=0.592\right)$ at both stations, with $\mathrm{BOD}_{5}$ at station I $\left(r_{1}=0.691\right)$, and with transparency $\left(r_{2}=0.508\right)$, alkalinity $\left(r_{2}=0.461\right)$, hardness $\left(r_{2}=0.605\right)$, chloride $\left(r_{2}=0.604\right)$, nitrate $\left(r_{2}=0.533\right)$ and dissolved organic matter $\left(r_{2}=\right.$ 0.480 ) at station II. Multiple regression indicates higher cumulative effect of 10 abiotic factors on their abundance $\left(R_{1}^{2}=0.954, R_{2}^{2}=0.934\right)$ at both sampling stations.

Amongst different genera of the Brachionidae, Brachionus $(43 \pm 29$ and $33 \pm 23 \mathrm{n} / \mathrm{l})>$ Keratella $(30 \pm 20$ and $33 \pm 16 \mathrm{n} / \mathrm{l})>$ Platyias $(14 \pm 9$ and $11 \pm 8 \mathrm{n} / \mathrm{l})$ are quantitatively important. In general, numerical significance of these genera agrees with the results of Sharma (2006) while that of the first genus confirms with the report of 


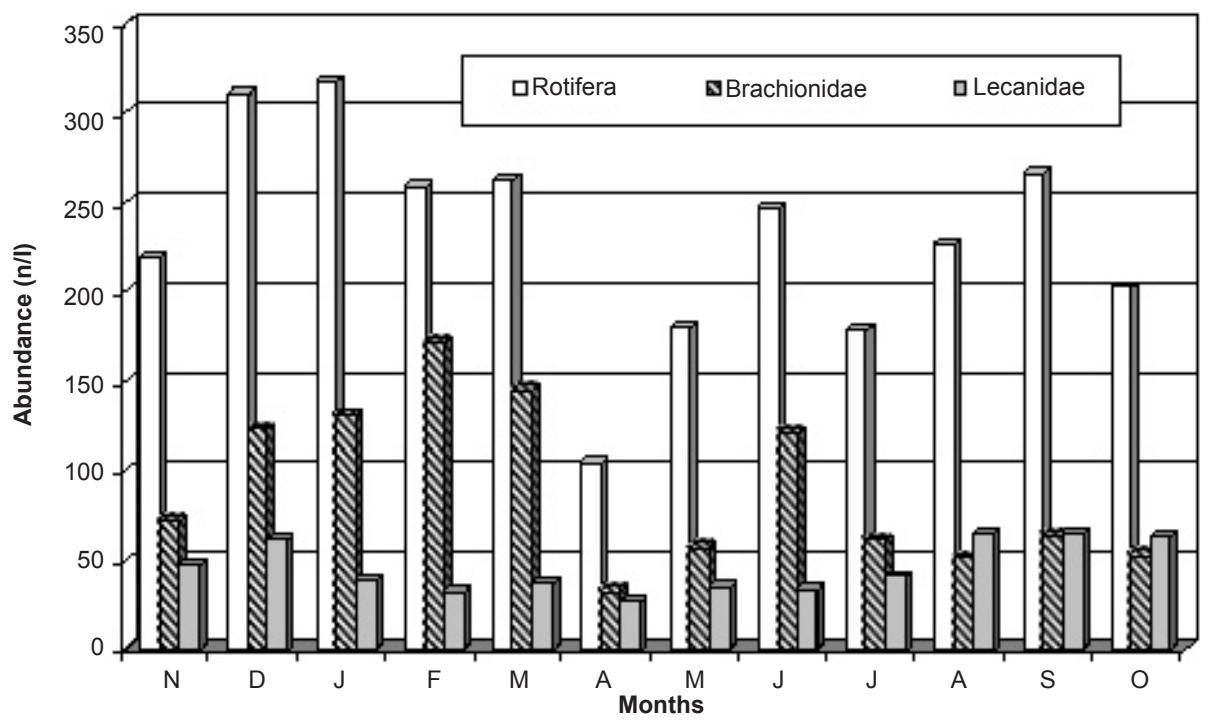

Figure 4. Monthly variations in abundance of Rotifera and important families (Station I)

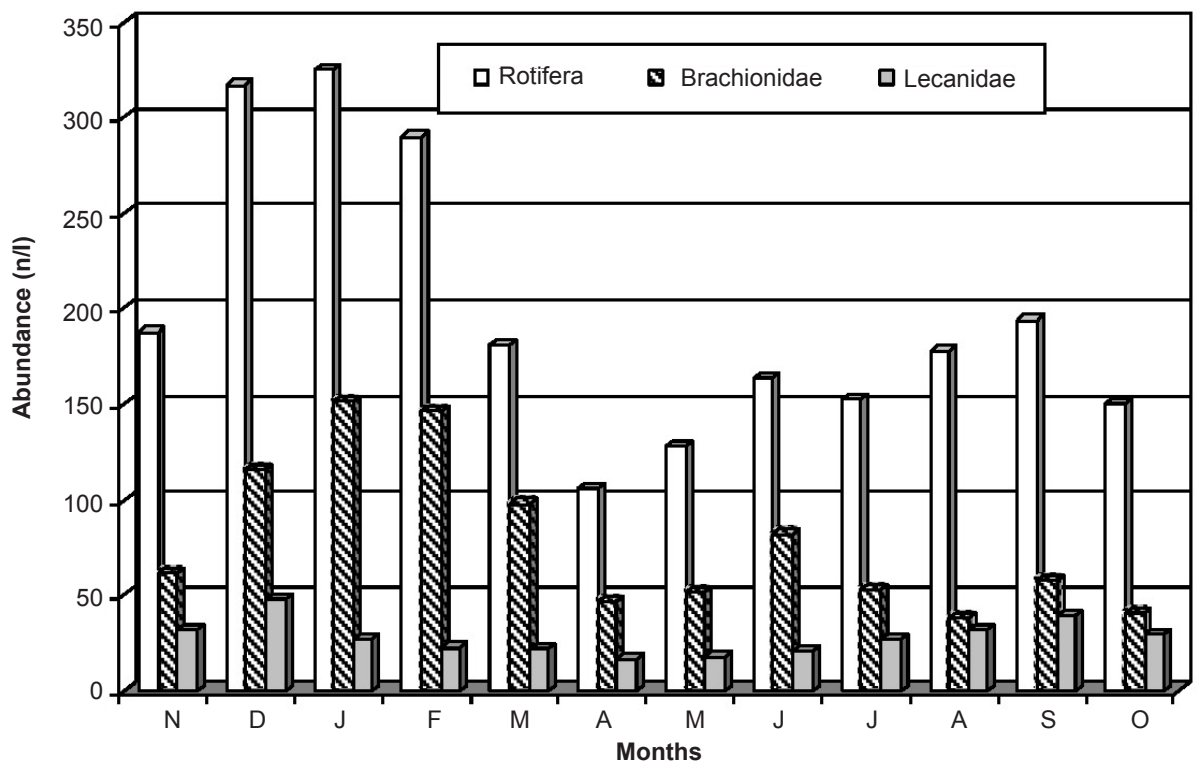

Figure 5. Monthly variations in abundance of Rotifera and important families (Station II)

Sharma (2000b). Brachionus spp. register significant temporal variations between months $\left(F_{11,23}=16.889, p<\right.$ $0.005)$ as well as stations $\left(F_{1,23}=7.387, p<0.02\right)$; they follow broadly unimodal patterns with peaks during March and February, relatively higher densities during JanuaryMarch, and minima during November and August at two sampling stations respectively. This genus is positively correlated with chloride $\left(r_{1}=0.457\right)$ and $\mathrm{BOD}_{5}\left(r_{1}=0.620\right)$ at station I and with specific conductivity $\left(r_{2}=0.462\right)$ at station II while it is negatively correlated with calcium $\left(r_{1}=-0.612\right)$ at station I and with water temperature at station II $\left(r_{2}=-0.591\right)$. Keratella shows significant density variations only between months $\left(F_{11,23}=10.927, p<\right.$ 0.005 ) and follows broadly bimodal and trimodal annual patterns at two stations respectively with peaks during June (station I) and January (station II). Its abundance is positively correlated with specific conductivity at both stations $\left(r_{1}=0.481, r_{2}=0.462\right)$ and is negatively correlated with magnesium at station I $\left(r_{1}=-0.557\right)$ and with water temperature at station II $\left(r_{2}=-0.646\right)$. Platyias exhibits bimodal and trimodal quantitative annual patterns; it records peaks during winter (December) and minima during summer (April) at both stations and registers only significant monthly variations $\left(F_{11,23}=10.811, p<0.005\right)$. This genus is negatively correlated with water temperature $\left(r_{1}=-0.703, r_{2}=-0.717\right)$ and rainfall $\left(r_{1}=-0.672, r_{2}=-0.614\right)$ and is positively correlated with transparency $\left(r_{1}=0.668\right.$, $\left.r_{2}=0.528\right)$, specific conductivity $\left(r_{1}=0.713, r_{2}=0.533\right)$ 
Table 3. Rotifera community similarities of Deepor Beel (Station I)

\begin{tabular}{|c|c|c|c|c|c|c|c|c|c|c|c|c|}
\hline & Nov & Dec & Jan & Feb & March & Apr & May & June & July & Aug & Sep & Oct \\
\hline Nov & - & 66.7 & 73.0 & 88.1 & 80.7 & 51.0 & 85.7 & 65.5 & 78.0 & 73.7 & 76.4 & 74.1 \\
\hline Dec & & - & 76.2 & 74.6 & 66.7 & 66.7 & 60.7 & 69.0 & 67.8 & 77.2 & 69.1 & 66.7 \\
\hline Jan & & & - & 77.4 & 76.7 & 59.3 & 71.2 & 72.1 & 77.4 & 76.7 & 75.9 & 66.7 \\
\hline Feb & & & & - & 85.7 & 56.0 & 80.0 & 63.2 & 82.8 & 82.1 & 81.5 & 79.3 \\
\hline March & & & & & - & 62.5 & 64.2 & 61.8 & 75.0 & 66.7 & 76.9 & 70.6 \\
\hline April & & & & & & - & 55.3 & 65.3 & 56.0 & 58.3 & 65.2 & 48.9 \\
\hline May & & & & & & & - & 66.7 & 72.7 & 71.7 & 70.6 & 68.0 \\
\hline June & & & & & & & & - & 63.2 & 69.1 & 60.4 & 61.5 \\
\hline July & & & & & & & & & - & 85.7 & 74.1 & 75.5 \\
\hline Aug & & & & & & & & & & - & 73.1 & 74.5 \\
\hline Sept & & & & & & & & & & & - & 57.1 \\
\hline Oct & & & & & & & & & & & & - \\
\hline
\end{tabular}

Table 4. Rotifera community similarities of Deepor Beel (Station II)

\begin{tabular}{|c|c|c|c|c|c|c|c|c|c|c|c|c|}
\hline & Nov & Dec & Jan & Feb & March & Apr & May & June & July & Aug & Sep & Oct \\
\hline Nov & - & 71.9 & 71.0 & 75.4 & 76.7 & 63.0 & 70.0 & 67.8 & 71.2 & 76.2 & 76.7 & 74.6 \\
\hline Dec & & - & 89.7 & 73.7 & 60.7 & 56.0 & 64.3 & 65.4 & 69.1 & 78.0 & 82.1 & 72.7 \\
\hline Jan & & & - & 80.0 & 70.4 & 62.5 & 63.0 & 71.7 & 71.7 & 77.2 & 77.8 & 75.5 \\
\hline Feb & & & & - & 75.5 & 68.1 & 71.7 & 65.4 & 80.8 & 71.4 & 79.3 & 84.6 \\
\hline March & & & & & - & 73.9 & 76.9 & 70.6 & 74.5 & 58.2 & 73.1 & 74.5 \\
\hline April & & & & & & - & 69.6 & 66.7 & 66.7 & 53.1 & 65.2 & 66.7 \\
\hline May & & & & & & & - & 70.6 & 66.7 & 66.5 & 69.2 & 66.7 \\
\hline June & & & & & & & & - & 76.0 & 70.4 & 62.8 & 60.0 \\
\hline July & & & & & & & & & - & 66.7 & 70.6 & 72.0 \\
\hline Aug & & & & & & & & & & - & 69.1 & 70.4 \\
\hline Sept & & & & & & & & & & & - & 78.4 \\
\hline Oct & & & & & & & & & & & & - \\
\hline
\end{tabular}

and dissolved oxygen $\left(r_{1}=0.801, r_{2}=0.640\right)$ at both the sampling stations. Besides, it registers positively correlation with alkalinity $\left(r_{1}=0.490\right)$, hardness $\left(r_{1}=0.609\right)$ and phosphate $\left(r_{1}=0.537\right)$ at station $\mathrm{I}$.

Lecanidae $(45 \pm 13 \mathrm{n} / \mathrm{l}$ and $29 \pm 9 \mathrm{n} / \mathrm{l})$, represented by genus Lecane, form sub-dominant component $(20.3 \pm$ $7.9 \%$ and $15.0 \pm 3.9 \%$ ) of Rotifera (Table 2 ); they record significant variations between months $\left(F_{11,23}=7.235, p<\right.$ $0.001)$ and stations $\left(F_{1,23}=53.597, p<0.005\right)$. This family follows multimodal and bimodal (Figs. 4 \& 5) annual patterns at two stations respectively, register peaks during August and September (station I) and December (station II) and record minima during April at both stations. The former feature is affirmed by their significant negative correlation with water temperature $\left(r_{1}=-0.573, r_{2}=-0.786\right)$. The Lecanids are negatively correlated with magnesium at station I $\left(r_{1}=-0.799\right)$ and with free $\mathrm{CO}_{2}$ at station II $\left(r_{2}\right.$ $=-0.492)$. Besides, this family is positively correlated with specific conductivity $\left(r_{1}=0.580, r_{2}=0.592\right)$ at both stations, with $\mathrm{BOD}_{5}$ at station $\mathrm{I}\left(r_{1}=0.691\right)$, and with transparency $\left(r_{2}=0.508\right)$, alkalinity $\left(r_{2}=0.461\right)$, hardness $\left(r_{2}=0.605\right)$, chloride $\left(r_{2}=0.604\right)$, nitrate $\left(r_{2}=0.533\right)$ and dissolved organic matter $\left(r_{2}=0.480\right)$ at station II. Multiple regression indicates higher cumulative effect of 10 abiotic factors on their abundance $\left(R_{1}{ }^{2}=0.954, R_{2}{ }^{2}=0.934\right)$ at both stations. In general, the sub-dominant role of the Lecanidae concurs with the results of Sharma (2006).

The Brachionidae mainly contribute to Rotifera peaks during January (winter) and to their primary maxima during July while the Brachionidae and Lecanidae contribute nearly equally to secondary maxima during September. In addition, three Eurotatorien families namely Asplanchnidae $(19 \pm 15$ and $18 \pm 13 \mathrm{n} / \mathrm{l})>$ Synchaetidae $(11 \pm 9$ and $13 \pm 8 \mathrm{n} / \mathrm{l})>$ Trochosphaeridae $(11 \pm 8$ and $10 \pm 6 \mathrm{n} / \mathrm{l})$ deserve mention in this study while Trichocercidae and Lepadellidae show still lower 


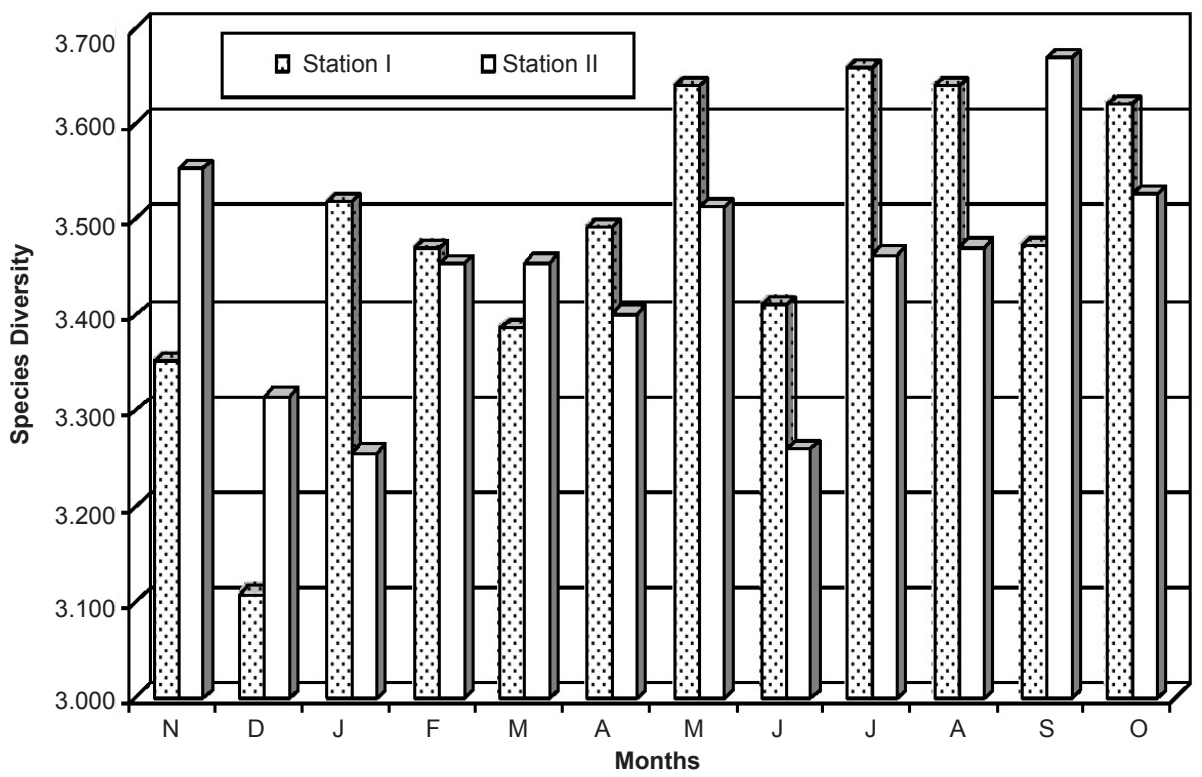

Figure 6. Monthly variations in species diversity of Rotifera

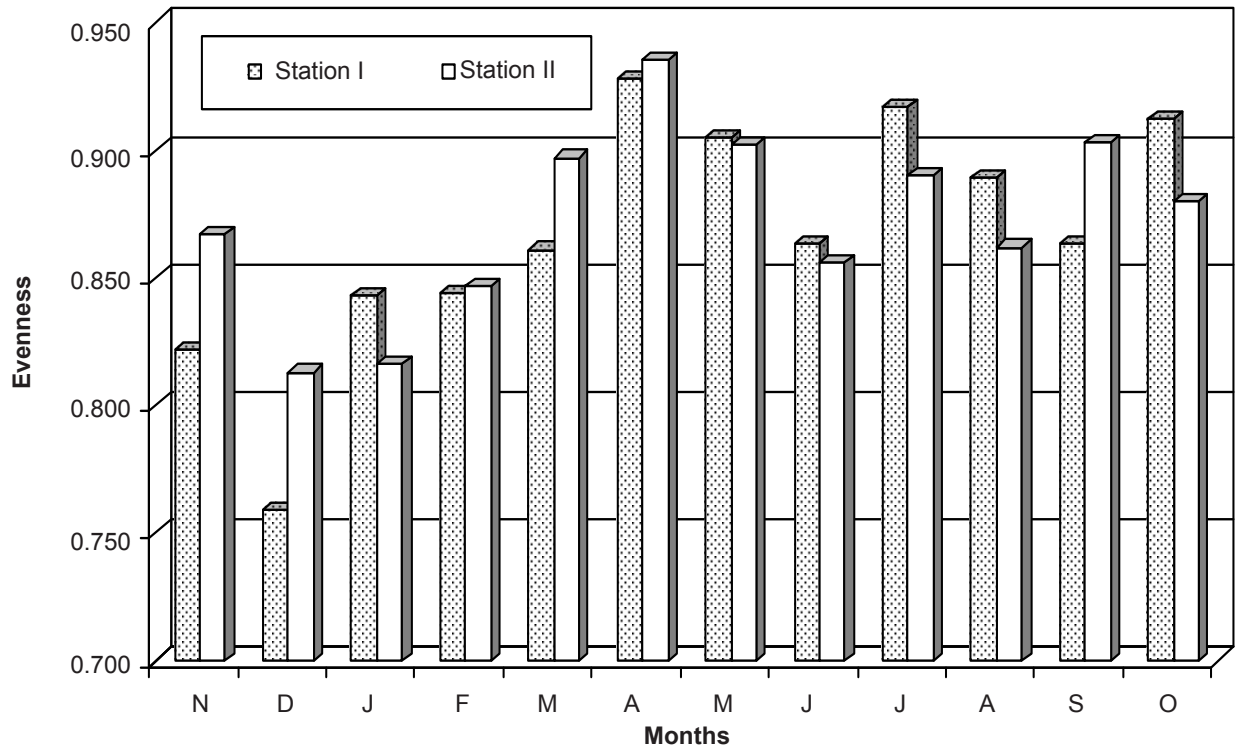

Figure 7. Monthly variations in evenness of Rotifera

densities. Referring to different genera, Brachionus $>$ Keratella > Lecane > Asplanchna and Keratella > Brachionus $>$ Asplanchna mainly contribute to Rotifera peaks at two sampling stations respectively. On the other hand, Brachionus > Lecane > Keratella and Keratella $>$ Lecane; Lecane > Brachionus > Asplanchna and Lecane $>$ Keratella $>$ Brachionus primarily contribute to their primary and secondary maxima respectively at two stations. Insufficient analysis of Rotifera taxa in various studies in the Indian floodplain lakes do not facilitate any such comparison with the present results though certain comments on importance of Brachionidae and Lecanidae are made earlier by Sharma (2000b, 2006).
Interestingly, amongst rich Rotifer biodiversity (110 species) observed in Deepor Beel, only a few species namely Asplanchna priodonta, Keratella cochlearis, Platyias quadricornis, Lecane leontina, Polyarthra vulgaris, Keratella tropica and Brachionus falcatus indicate certain degree of quantitative importance while no individual species shows distinct dominance. On the other hand, the present results are characterized by lower densities of majority of species as well as lack of any definite pattern of quantitative periodicity of any particular family, genus or species. This salient feature stands in contrast to importance of certain species indicated by Sharma (2000b) and Sharma \& Sharma (2008). 


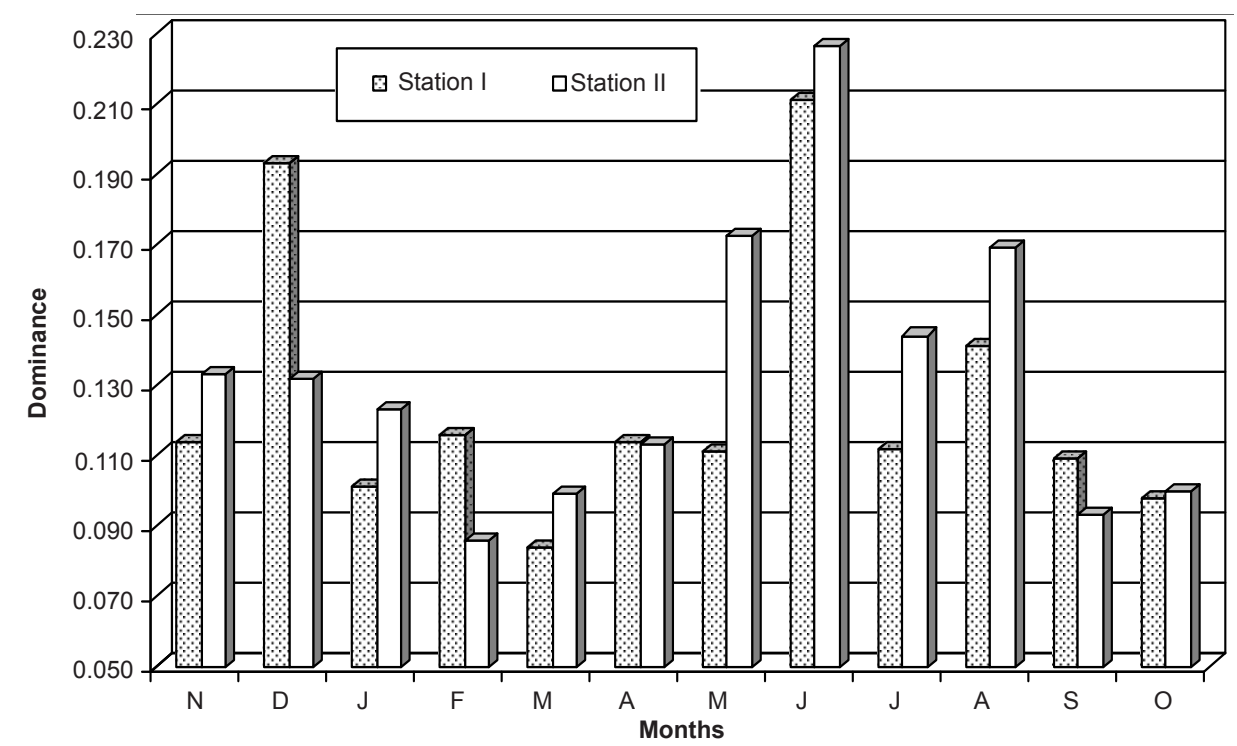

Figure 8. Monthly variations in dominance of Rotifera

The rotifer communities of Deepor Beel (Table 2) are characterized by higher species diversity $(3.480 \pm 0.150$ and $3.445 \pm 0.116$ ) which, in turn, indicates only marginal differences at two stations and registers insignificant variations between months as well as stations. It follows (Fig. 6) multimodal but different annual patterns with peaks during July and October and minima during December and January at two sampling stations respectively. The present results indicate significantly higher species diversity than the report of Sharma (2000b) and Sharma \& Hussain (2001) and, even higher values than those of the rotifer communities of various floodplain lakes of Assam (Sharma 2005, 2006; Sharma \& Sharma 2008). The rotifer diversity is negatively correlated with their abundance $\left(r_{1}=-0.510, r_{2}=-0.414\right)$. The salient feature of higher species diversity with relatively lower numbers (density) of majority of species noticed in this study may be ascribed to fine niche portioning amongst rotifers species in combination with high micro- and macro-scale habitat heterogeneity as hypothesized by Segers (2008). This generalization affirms earlier remarks of Sharma (2009).

The rotifers indicate higher evenness $(0.867 \pm 0.046$ and $0.872 \pm 0.035$ ) in the present study (Table 2); this salient feature re-affirms equitable abundance of various species and also concurs with the findings in the floodplain lakes of Assam (Sharma 2005, 2006; Sharma \& Sharma, 2008) and Manipur (Sharma 2009). Evenness registers significant variations between months $\left(F_{11,23}=5.197, p\right.$ $<0.005$ ) and insignificant between stations. Further, it follows (Fig. 7) multimodal but broadly identical annual patterns, shows peaks during April (summer) and minima during December (winter) at both stations. Evenness is negatively correlated with rotifer abundance $\left(r_{1}=-0.789\right.$, $\left.r_{2}=-0.870\right)$ and is positively correlated with their species diversity $\left(r_{1}=0.867, r_{2}=0.569\right)$ at both sampling stations.

The present study indicates (Table 2) lower Rotifera dominance $(0.125 \pm 0.037$ and $0.133 \pm 0.039)$ which, in turn, registers significant temporal variations between months $\left(F_{11,23}=6.285, p<0.005\right)$ and insignificant variations between stations. The salient feature of lower dominance concurs with the findings of Sharma (2005, 2006) and Sharma \& Sharma (2008) from other floodplain lakes of Assam as well as those of Sharma (2009) from Loktak Lake, Manipur. Dominance follows multimodal annual patterns with peaks during summer (April) but records minima during March (station I) and February (station II). It is negatively correlated with species diversity $\left(r_{1}=-0.491, r_{2}=-0.443\right)$ at both stations and only with Rotifera evenness at station II $\left(r_{2}=-0.458\right)$.

Sladecek (1983) proposed $Q_{B / T}$ quotient based on the ratios between Brachionus: Trichocerca species to depict trophic status of different ecosystems or even individual samples. Sharma \& Dudani (1992) and Sharma (2000a) successfully applied it to certain aquatic ecosystems under the Indian conditions. Application of the stated quotient to the rotifer communities of Deepor Beel indicates $Q_{B / T}$ ratios of $3.01 \pm 1.0$ and $2.87 \pm 0.8$, thereby, reflecting eutrophic status of this floodplain lake.

To sum up, Rotifera communities of Deepor Beel are highly diverse and speciose, form important qualitative and quantitative components of zooplankton and indicate no definite periodicity of occurrence or abundance of any family, group or species. They are characterized by lower densities of majority of species, relative quantitative importance of fewer species, higher species diversity, higher evenness and lower dominance. The present results indicate limited influence of individual abiotic factors, while ten abiotic factors exert higher cumulative influence on Rotifera richness and abundance. $Q_{B / T}$ 
quotient reflects eutrophic status of this Ramsar site.

\section{REFERENCES}

APHA (1992). Standard methods for the examination of water and wastewater (18 ${ }^{\text {th }}$ ed.). American Public Health Association, Washington D. C.

Baruah, A., A.K. Sinha \& U.P. Sharma (1993). Plankton variability of a tropical wetland, Kawar (Begusarai), Bihar. Journal of Freshwater Biology 5: 27-32.

Khan, M.A. (1987). Observations on Zooplankton composition, abundance and periodicity in two flood plain lakes of the Kashmir Himalayan valley Acta Hydrochemica Hydrobiologia 15: 167174

Khan, R.A. (2002). The ecology and faunal diversity of two floodplain Ox-bow lakes of South-Eastern West Bengal. Records of the Zoological Survey of India, Occasional Paper No. 195: 1-57.

Khan, R.A. (2003). Faunal diversity of zooplankton in freshwater wetlands of Southeastern West Bengal. Records of the Zoological Survey of India, Occasional Paper No. 204: 1-107.

Koste, W. (1978). ROTATORIA. Die Rädertiere Mitteleuropas, begründet von Max Voigt. Überordnung Monogononta. Gebrüder Borntraeger, Berlin, Stuttgart. I. Text (673 pp) U. II. Tafelbd. (T. 234).

Ludwig, J.A. \& J.F. Reynolds (1988). Statistical ecology: a primer on methods and computing. John Wiley \& Sons, New York, 337pp.

Magurran, A.E. (1988). Ecological diversity and its measurement. Croom Helm Limited, London, 179pp.

Sarma, P.K. (2000). Systematics, distribution and ecology of zooplankton of some floodplain wetlands of Assam, India. PhD thesis, Gauhati University, Assam.

Sanjer, L.R. \& U.P. Sharma (1995). Community structure of plankton in Kawar lake wetland, Begusarai, Bihar: II Zooplankton. Journal of Freshwater Biology 7: 165-167.

Segers, H. (1995). Rotifera 2: Lecanidae, 6: 1-226. In: Dumont, H.J. \& T. Nogrady (eds.) Guides to Identification of the Microinvertebrates of the Continental Waters of the World. SPB Academic Publishing bv. Amsterdam, The Netherlands.

Segers, H. (2008). Global diversity of rotifers (Rotifera) in freshwater. Hydrobiologia 595: 49-59.

Segers, H., C.S. Nwadiaro \& H.J. Dumont (1993). Rotifera of some lakes in the floodplain of the river Niger (Imo State, Nigeria). II. Faunal composition and diversity. Hydrobiologia 250: 63-71.

Sharma, B.K. (1992). Systematics, Distribution and Ecology of Freshwater Rotifera in West Bengal, pp.231-273. In: Mishra, S.R. \& D.N. Saksena (eds.). Recent Advances in Aquatic Ecology, Chapter, 14.
Sharma, B.K. (1998). Freshwater Rotifers (Rotifera: Eurotatoria), pp.341-461. In: Fauna of West Bengal. State Fauna Series 3(11). Zoological Survey of India, Calcutta.

Sharma, B.K. (2000a). Rotifers from some tropical flood-plain lakes of Assam (N.E. India). Tropical Ecology 41(2): 175181.

Sharma, B.K. (2000b). Synecology of Rotifers in a tropical floodplain lake of Upper Assam (N. E. India). The Indian Journal of Animal Sciences 70: 880-885.

Sharma, B.K. (2005). Rotifer communities of floodplain lakes of the Brahmaputra basin of lower Assam (N. E. India): biodiversity, distribution and ecology. Hydrobiologia 533: 209-221.

Sharma, B.K. (2009). Diversity of Rotifers (Rotifera: Eurotatoria) of Loktak lake, north-eastern India. Tropical Ecology 50(2): 277-285.

Sharma, B.K. \& V.K. Dudani (1992). Rotifers from some tropical ponds in Bihar: species composition, similarities and trophic indicators. Journal of Indian Institute of Sciences 72: 121130.

Sharma, B.K. \& M. Hussain (2001). Abundance and Ecology of Zooplankton in a tropical floodplain lake, Assam (N. E. India). Ecology, Environment \& Conservation 7(4): 397-403.

Sharma, B.K. \& S. Sharma (1999). Freshwater Rotifers (Rotifera: Eurotatoria), pp.11-161. In: State Fauna Series: Fauna of Meghalaya, 4(9). Zoological Survey of India, Calcutta.

Sharma, B.K. \& S. Sharma (2000). Freshwater Rotifers (Rotifera: Eurotatoria), pp.163-224. In: State Fauna Series: Fauna of Tripura 7(4). Zoological Survey of India, Calcutta.

Sharma, B.K. \& S. Sharma (2001). Biodiversity of Rotifera in some tropical floodplain lakes of the Brahmaputra river basin, Assam (N. E. India). Hydrobiologia 446 / 447: 305-313.

Sharma, B.K. \& S. Sharma (2005). Faunal diversity of Rotifers (Rotifera: Eurotatoria) of Deepor beel, Assam (N. E. India)- a Ramsar site. Journal of the Bombay Natural History Society 102(2): 169-175.

Sharma, S. (2006). Rotifer diversity (Rotifera : Eurotatoria) of floodplain lakes of Pobitora Wild-Life Sanctuary, Assam. Records of the Zoological Survey of India 106(3): 76-89.

Sharma, S. \& B.K. Sharma (2008). Zooplankton diversity in floodplain lakes of Assam. Records of the Zoological Survey of India, Occasional Paper No. 290: 1-307.

Sinha, A.K., A. Baruah, D.K. Singh \& U.P. Sharma (1994). Biodiversity and pollution status in relation to physicochemical factors of Kawar lake Begusarai), North Bihar. Journal of Freshwater Biology 6: 309-331.

Sladecek, V. (1983). Rotifera as indicators of water quality. Hydrobiologia 100: 169-201.

Talling J.F. \& I.B. Talling (1965). The chemical composition of African lake waters. Internationale Revue gesammten Hydrobiologie 50: 421-463.

Yadava, Y.S., R.K. Singh, M. Choudhury \& V. Kolekar (1987). Limnology and productivity in Dighali beel (Assam). Tropical Ecology 28: 137- 146. 